\title{
SERUM CREATINE KINASE MB IN ISCHAEMIC STROKE: A CASE CONTROL STUDY
}

\author{
B. Preethi' ${ }^{1}$, C. Ramakrishna², M. Roopa ${ }^{3}$, Sanjeevi Rao 4
}

${ }^{1}$ Assistant Professor, Department of Biochemistry, NRI Institute of Medical Sciences, Sangivalasa, Vishakapatnam. ${ }^{2}$ Assistant Professor, Department of Biochemistry, NRI Institute of Medical Sciences, Sangivalasa, Vishakapatnam. ${ }_{3}^{3}$ Associate Professor, Department of Biochemistry, NRI Institute of Medical Sciences, Sangivalasa, Vishakapatnam. 4 Professor and HOD, Department of Biochemistry, NRI Institute of Medical Sciences, Sangivalasa, Vishakapatnam.

\section{ABSTRACT}

AIM

To estimate CK-MB levels in ischaemic stroke patients and know its correlation in stroke patients.

\section{OBJECTIVES}

Serum creatine kinase-MB, other cardiac enzymes (CK, SGOT), uric acid, lipid profile, fasting blood glucose, and blood pressure was recorded. CT scan and ECG were also considered for the study. The aim of study was to determine serum creatine kinase-MB and the vascular risk factors for ischaemic stroke in a series of patients with an ischaemic stroke and to compare them with a series of controls of same age.

\section{METHODS}

Fifty (50) consecutive patients with ischaemic stroke were compared with thirty (30) healthy controls of same age. Vascular risk factors were recorded and serum creatine kinase-MB was determined in all of them.

\section{RESULTS}

There was modest rise of CK-MB in initial stages of stroke as compared with controls. The increase in CK-MB among cases is highly significant with a P value of $<0.001$.

\section{CONCLUSION}

The modest rise in serum CK-MB, which have recorded in the initial stages of stroke suggest that acute myocardial involvement is a common complication than is generally recognized. It is more likely that acute myocardial dysfunction is a consequence rather than a cause of acute cerebrovascular lesion.

\section{KEYWORDS}

Stroke, Creatine, Kinase-MB, Creatine kinase.

HOW TO CITE THIS ARTICLE: Preethi B, Ramakrishna C, Roopa M, et al. Serum creatine kinase MB in ischaemic stroke: a case control study. J. Evolution Med. Dent. Sci. 2016; 5(52):3386-3390, DOI: 10.14260/jemds/2016/782

\section{INTRODUCTION}

The word "Stroke" is used to refer to a clinical syndrome of presumed vascular origin, typified by rapidly developing signs of focal or global disturbance of cerebral functions lasting more than twenty four hours or leading to death. ${ }^{1}$ (World health organization 1978).

For years, strokes have been subdivided pathologically into infarcts (thrombotic or embolic) and haemorrhages \& clinical criteria for distinguishing between these possibilities have been emphasized. ${ }^{2}$

It effects between 174 \& 216 people per 100000 population in UK each year (Man et al 2004) and accounts for $11 \%$ of all deaths in England \& Wales. It is accepted that $85 \%$ of strokes are due to cerebral infarction, $10 \%$ due to primary haemorrhage $5 \%$ due to subarachnoid haemorrhage. The risk of recurrent stroke is $26 \%$ within 5 years of a first stroke and $39 \%$ by 10 years (Mohan et al 2011). ${ }^{3}$

Financial or Other, Competing Interest: None.

Submission 20-04-2016, Peer Review 07-06-2016,

Acceptance 13-06-2016, Published 29-06-2016.

Corresponding Author:

Dr. C. Ramakrishna

Door No. 48-6-33, Srinagar

Vishakapatnam-530016

Andhra Pradesh

E-mail: ramjeerk@gmail.com

DOI: $10.14260 /$ jemds/2016/782
Thus, the definition of stroke is clinical and laboratory studies including brain imaging are used to support the diagnosis. ${ }^{4}$

Brain is a rich source of a variety of enzymes and any injury like stroke to brain tissue could similarly result in an increase in activity of these enzymes in cerebrospinal fluid and serum. It was in this context that the present study was done to assess the levels of enzymes like aspartate aminotransferase (AST), creatine kinase (CK) and isoenzyme of creatine kinase (CK$\mathrm{MB}$ ) in serum. CK has three isoenzymes CK-MM, CK-MB, CKBB. Myocardial damage has been shown to be associated with cerebrovascular accident and in present study overall raised values of $\mathrm{CK}$ was consistent with routine ECG and Holter monitor changes and may be an indicator of associated myocardial damage.

Uric acid is the end product of purine metabolism. Increased uric acid levels have been found to be associated with established risk factors of stroke such as hypertension, dyslipidaemia, obesity and diabetes mellitus. ${ }^{5}$ Also significantly higher risk of stroke incidence and mortality was reported in cases of hyperuricemia. 6

Evaluation of enzyme levels and easily available method for the evaluation of severity, course, prognosis, and to some extent in the differential diagnosis of various types of cerebrovascular accidents. ${ }^{7}$

Serum creatine kinase, creatine kinase-MB and aspartate aminotransferase levels were raised above normal in stroke 
patients. The values of $\mathrm{CPK}$ and CPK-MB were well above normal limits in $72 \%$, and $54 \%$ of patients respectively on day 1. Aspartate aminotransferase levels were marginally raised. The present study aims to estimate serum SGOT, CK (total) and CK-MB and uric acid. In addition, other parameters estimated are fasting plasma glucose, cholesterol, triglycerides, serum HDL cholesterol, serum LDL cholesterol, serum VLDL cholesterol.

\section{MATERIALS AND METHODS}

The present study was conducted on fifty (50) patients of ischaemic stroke admitted in medical wards and casualty of NRI Hospital, Vishakapatnam (With mean age 56.5 years) during the period of 2015. Out of Fifty (50) cases, Thirty Three (33) are men and Seventeen (17) are women.

The study included Thirty (30) healthy control subjects who are age matched and sex matched with patients. Out of Thirty (30), Twenty (20) are men and Ten (10) are women.

Blood samples for serum enzymes were taken within 2472 hours of onset of symptoms and serum enzymes, uric acid were estimated. Fasting blood sample collected for lipid profile and blood sugar on the next day of admission. Blood pressure recorded in right upper limb in supine position with Hg Sphygmomanometer. Creatine Kinase (Total), Creatine Kinase-MB, Aspartate Transaminase, lipid profile, Fasting Blood Sugar were estimated in control group also.

A detailed history was taken considering various risk factors for stroke like hypertension, smoking, diabetes mellitus, alcoholism, and previous stroke from study group. CT scan was done to differentiate various causes of stroke. Only ischaemic causes showing CT scans were taken into consideration and 50 cases showing positive findings for ischaemic stroke were taken for evaluation of present study. CT scans were done immediately after admission. Parameters were analysed immediately after collection of sample.

\section{Inclusion Criteria}

Patients clinically diagnosed to have ischaemic stroke were selected for the study.

\section{Exclusion Criteria}

Traumatic and space occupying lesions of cerebrovascular disease are excluded form study by history and Computed Tomography Scan impression. Patients with previous myocardial infarction or present myocardial infarction and patients with recent infections, liver disease, and renal failures are excluded.

\section{The Following Investigations Were Performed}

1. Estimation of Fasting Blood Sugar.

2. Serum Total Cholesterol, Triglycerides, HDL, LDL, and VLDL cholesterol.

3. Creatine Kinase (CK)-Total.

4. Creatine Kinase-MB (CPK-MB).

5. Serum Glutamate Oxaloacetate Transaminase (SGOT).

6. Uric Acid.

7. Also E.C.G. and C.T. Scan brain were considered for study.
Blood glucose was estimated by glucose oxidase peroxidase method. Creatine kinase was assayed by UV kinetic (IFCC) method \& creatine kinase-MB was assayed by following procedure. This procedure involves measurement of creatine kinase activity in the presence of an antibody completely inhibits the activity of creatine kinase-MM and half of the $\mathrm{B}$ subunit activity of creatine kinase-MB and creatine kinase-BB. Then, we use the creatine kinase method to quantitatively determine creatine kinase-B activity, the creatine kinase-MB activity is obtained by multiplying the creatine kinase- $B$ activity by two. Serum aspartate aminotransferase was estimated by UV kinetic (IFCC) method. Estimation of cholesterol and HDL cholesterol was done by CHOD - POD phosphotungstate method. Low density lipoprotein cholesterol (LDL-C) was calculated indirectly by Friedewald formula. Uric acid was estimated by enzymatic uricase method.

\section{Statistical Analysis}

It was done by applying the " $z$ " test. Significance between cases and controls values estimated by " $p$ " value.

\section{RESULTS}

Normal Values: - 20-170 IU/L

\begin{tabular}{|c|c|c|c|c|c|c|}
\hline & Mean & SD & $\begin{array}{c}\text { Mean } \\
\text { Difference }\end{array}$ & SE & $\begin{array}{c}\mathrm{Z} \\
\text { Static }\end{array}$ & $\begin{array}{c}\mathbf{P} \\
\text { Value }\end{array}$ \\
\hline $\begin{array}{l}\text { Cases } \\
\mathrm{n}=50\end{array}$ & 227.5 & 240.54 & \multirow[t]{2}{*}{157.07} & \multirow[t]{2}{*}{6.30} & \multirow[t]{2}{*}{24.93} & \multirow[t]{2}{*}{$\begin{array}{c}\mathrm{P} \\
<0.001\end{array}$} \\
\hline $\begin{array}{c}\text { Controls } \\
n=30\end{array}$ & 70.43 & 35.803 & & & & \\
\hline & & $\begin{array}{l}\text { I: Seru } \\
\text { in } C o\end{array}$ & Creatine $K$ & ase & & \\
\hline
\end{tabular}

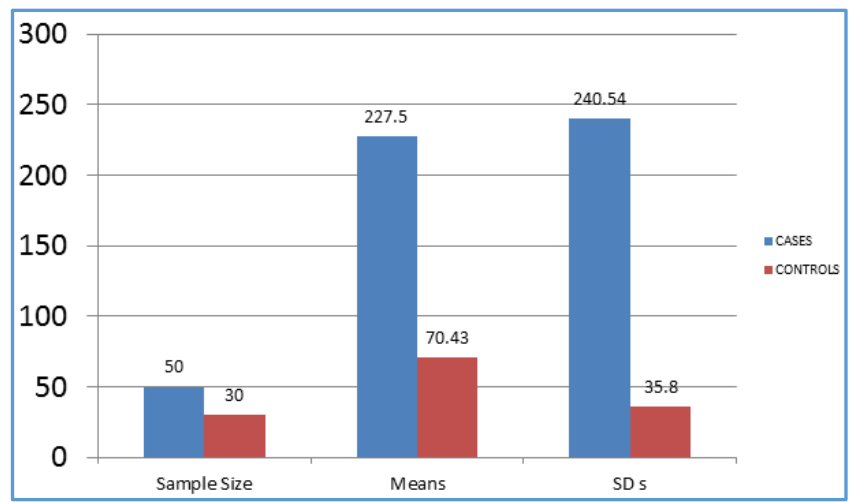

Fig. 1: Serum Creatine Kinase Levels in Cases and Controls

In the present study, mean value of creatine kinase among cases (Average) is $227.51 \mathrm{U} / 1 \pm 240.54$ (Mean $\pm \mathrm{SD}$ ) and that of controls is $70.43 \pm 35.803$. The increase in serum creatine kinase among cases is highly significant with a $\mathrm{p}$ value of $<0.001$. 
Normal Values: - 0-26 U/L

\begin{tabular}{|c|c|c|c|c|c|c|}
\hline & Mean & SD & Mean Difference & SE & Z Statistic & P Value \\
\hline Cases n=50 & 49.56 & 35.15 & 39.26 & 6.45 & 6.08 & P $<0.001$ \\
\hline Controls n=30 & 10.3 & 4.90 & & & \\
\hline
\end{tabular}

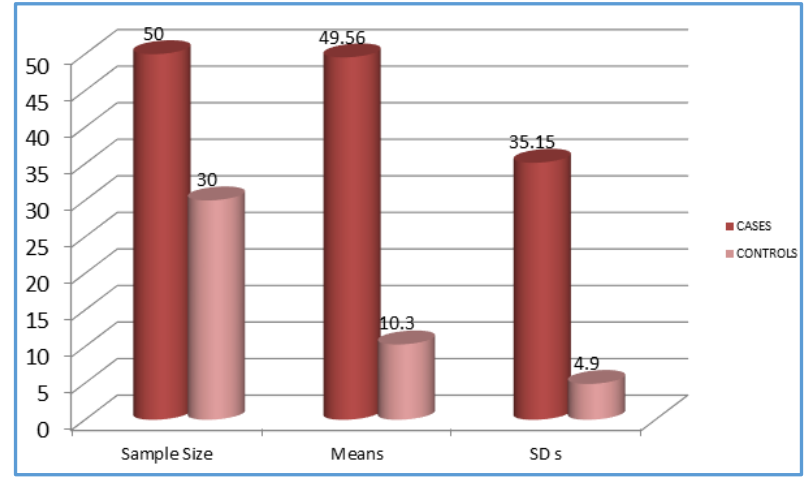

Fig. 2: Serum Creatine Kinase - MB Levels of Cases and Controls

In the present study, mean value of CPK-MB among cases (Average is $49.56 \pm 35.15$ (Mean $\pm \mathrm{SD}$ ) and that of controls is $10.3 \pm 4.90$. The increases in serum CPK-MB among cases is highly significant with a $\mathrm{p}$ value of $<0.001$.

Normal Values: 3 - $6 \mathrm{mg} / \mathrm{dL}$

\begin{tabular}{|c|c|c|c|c|c|c|}
\hline & Mean & SD & $\begin{array}{c}\text { Mean } \\
\text { Difference }\end{array}$ & $\begin{array}{c}\text { SE } \\
\text { (d) }\end{array}$ & $\begin{array}{c}\mathrm{Z} \\
\text { Statistic }\end{array}$ & $\begin{array}{c}\text { P } \\
\text { Value }\end{array}$ \\
\cline { 1 - 5 } $\begin{array}{c}\text { Cases } \\
\mathrm{n}=50\end{array}$ & 6.48 & 1.94 & 1.39 & 0.36 & 3.65 & $\begin{array}{c}\mathrm{P}< \\
0.001\end{array}$ \\
\hline $\begin{array}{c}\text { Controls } \\
\mathrm{n}=30\end{array}$ & 5.09 & 1.07 & & & & \\
\hline \multicolumn{7}{|c|}{ Table III: Serum Uric Acid Levels of Cases and Controls } \\
\hline
\end{tabular}

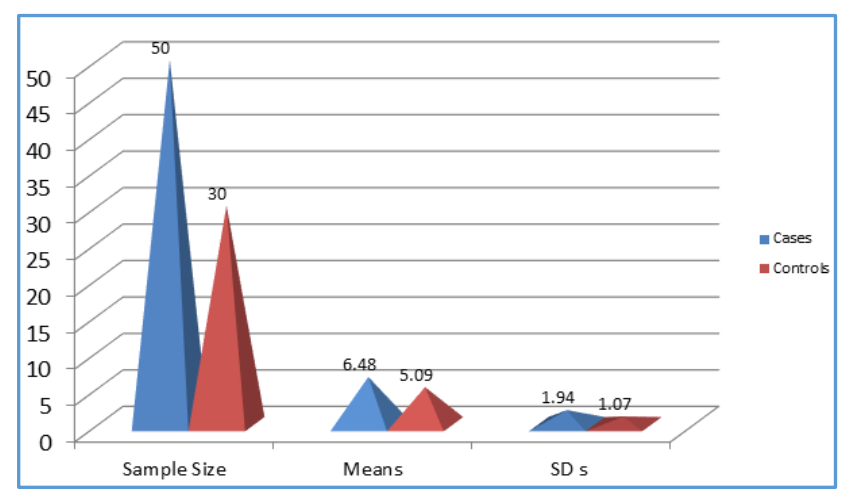

Fig. 3: Serum Uric Acid Levels in Cases and Controls

Normal Values: - 8-20 IU/L

\begin{tabular}{|c|c|c|c|c|c|c|}
\hline & Mean & SD & $\begin{array}{c}\text { Mean } \\
\text { Difference }\end{array}$ & $\begin{array}{c}\text { SE } \\
\text { (d) }\end{array}$ & $\begin{array}{c}\mathrm{Z} \\
\text { Static }\end{array}$ & $\begin{array}{c}\text { P } \\
\text { value }\end{array}$ \\
\hline $\begin{array}{c}\text { Cases } \\
\mathrm{n}=50\end{array}$ & 45.42 & 25.47 & 18.15 & 4.676 & 3.88 & $\begin{array}{c}\mathrm{P} \\
\text { Controls } \\
\mathrm{n}=30\end{array}$ \\
\hline \multicolumn{2}{|c|}{ Table IV: Serum SGOT Levels of Cases and Controls } \\
\hline
\end{tabular}

In the present study mean value of serum SGOT among cases (average) is $45.42 \mathrm{IU} / 1 \pm 25.47$ (mean $\pm \mathrm{SD}$ ) and that of controls is $27.77 \pm 3.682$. The increase in SGOT among cases is highly significant with a $\mathrm{p}$ value of $<0.001$.

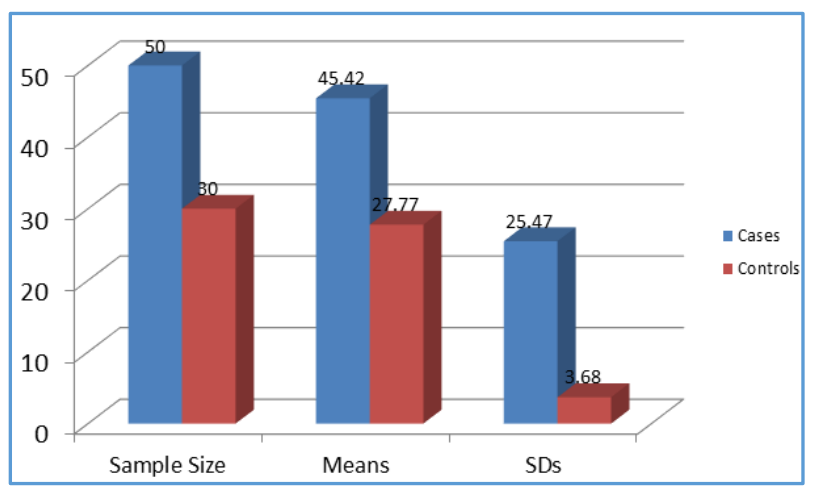

Fig. 4: Serum SGOT Levels of Cases and Controls

\begin{tabular}{|c|c|c|c|}
\hline Risk Factor & $\begin{array}{l}\text { Male } \\
\mathrm{N}=33\end{array}$ & $\begin{array}{c}\text { Females } \\
\mathrm{N}=17\end{array}$ & $\begin{array}{c}\text { Total } \\
\text { Patients } \\
\mathrm{N}=\mathbf{5 0}\end{array}$ \\
\hline Uric acid & $\begin{array}{c}30 \\
(90.90)\end{array}$ & $\begin{array}{c}10 \\
(58.82)\end{array}$ & $\begin{array}{c}40 \\
(80.00)\end{array}$ \\
\hline Hypertension & $\begin{array}{c}24 \\
(72.72)\end{array}$ & $\begin{array}{c}11 \\
(64.70)\end{array}$ & $\begin{array}{c}35 \\
(70.00)\end{array}$ \\
\hline Smoking & $\begin{array}{c}27 \\
(81.81)\end{array}$ & $\begin{array}{c}01 \\
(5.88)\end{array}$ & $\begin{array}{c}28 \\
(56.00)\end{array}$ \\
\hline Hypercholesterolemia & $\begin{array}{c}28 \\
(84.84)\end{array}$ & $\begin{array}{c}11 \\
(64.70)\end{array}$ & $\begin{array}{c}39 \\
(78.00)\end{array}$ \\
\hline DM & $\begin{array}{c}01 \\
(03.03)\end{array}$ & $\begin{array}{c}04 \\
(23.52)\end{array}$ & $\begin{array}{c}05 \\
(10.00)\end{array}$ \\
\hline LDL & $\begin{array}{c}28 \\
(84.84)\end{array}$ & $\begin{array}{c}09 \\
(52.94)\end{array}$ & $\begin{array}{c}08 \\
(10.00)\end{array}$ \\
\hline No risk factor & $\begin{array}{c}01 \\
(03.03)\end{array}$ & $\begin{array}{c}04 \\
(23.52)\end{array}$ & $\begin{array}{c}05 \\
(10.00)\end{array}$ \\
\hline
\end{tabular}

In the study, it is shown that uric acid constitutes $80 \%$, hypercholesterolemia 78\%, LDL 74\%, HTN 70\%, smoking $56 \%$, \& DM 10\%. So, it has been inferred that ischaemic stroke is associated positively with HTN, hypercholesterolemia, LDL, hyperuricemia, smoking, and DM as shown above.

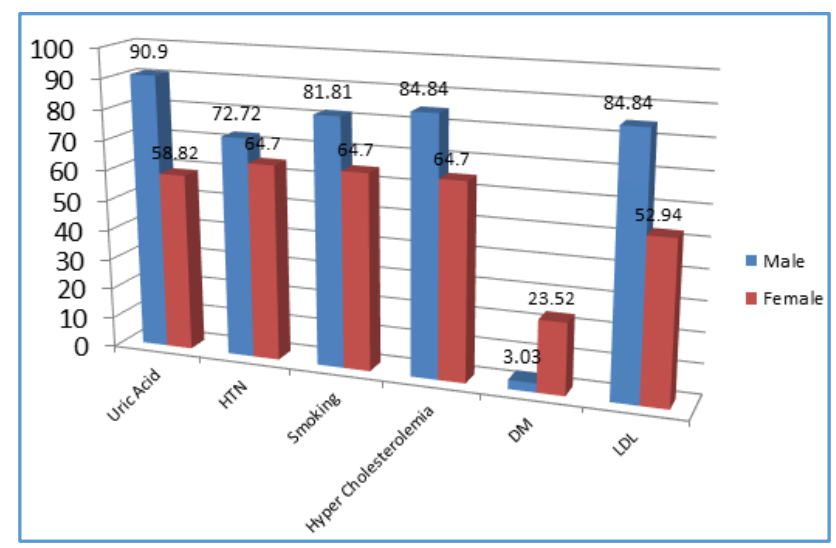

Fig. 5: Risk Factors in Ischaemic Stroke 


\begin{tabular}{|l|c|c|}
\hline & $\begin{array}{c}\text { Cholesterol } \\
\text { Mean } \pm \text { SD }\end{array}$ & $\begin{array}{c}\text { Triglycerides } \\
\text { Mean } \pm \text { SD }\end{array}$ \\
\hline Cases $\mathrm{n}=50$ & $215.92 \pm 26.95$ & $146.76 \pm 16.04$ \\
\hline Controls $\mathrm{n}=30$ & $184.7 \pm 24.76$ & $95.8 \pm 15.12$ \\
\hline $1 . \quad$ Mean $(\mathrm{d})$ & 31.22 & 50.96 \\
\hline 2. SE $(\mathrm{d})$ & 6.02 & 3.61 \\
\hline 3. Z Statistic & 5.73 & 14.11 \\
\hline 4. P value & $\mathrm{P}<0.001$ & $\mathrm{P}<0.001$ \\
\hline \multicolumn{2}{|c|}{ Table VI: Serum Cholesterol and Triglycerides } \\
Levels in Cases and Controls \\
\hline
\end{tabular}

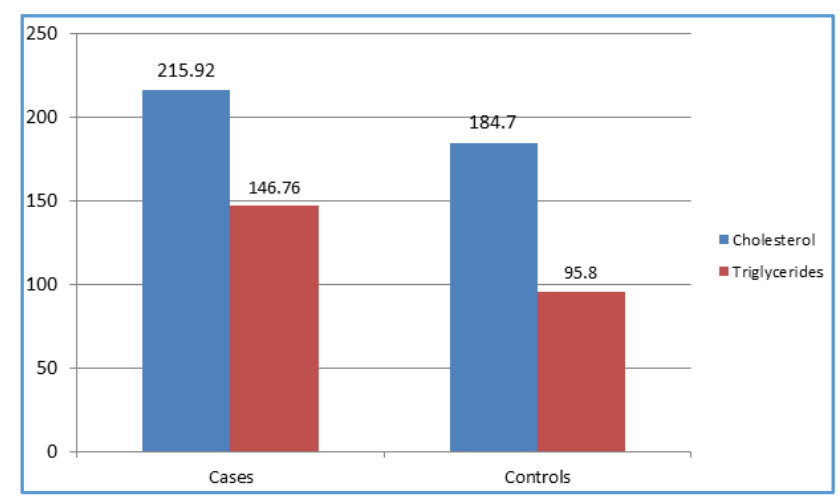

Fig. 6: Mean Serum Cholesterol and Triglycerides in Cases and Controls

\section{DISCUSSION}

Fifty (50) Ischaemic stroke patients were studied for Serum Enzymes, that is Creatine Kinase, Creatine Kinase-MB and Aspartate Transaminase. Thirty (30) age matched controls were taken for comparison. Present study included thirty three (33) male patients and seventeen (17) female patients. Age group varied from 41-70 years, majority falling between 51-60 years.

CPK-MB and total CK values in cases were increased significantly when compared to controls. The value of mean and SD of CPK-MB in cases is 49.56 and 35.15 respectively and in controls it is 10.3 and 4.90 respectively. The value of mean and SD of total CK in cases is 227.5 and 240.54 respectively and in controls it is 70.43 and 35.8 respectively. The above values indicate that CPK-MB and total CK are significantly elevated in ischaemic stroke patients.

The rise in CPK-MB in males was greater than the rise in females indicating that gender has a significant role in CPK-MB levels in ischaemic patients. CT scan was done to categorise the patients into ischaemic or haemorrhagic lesion.

History of hypertension was taken. Out of 50 cases 35 (70\%) had high blood pressure (Systolic more than $140 \mathrm{~mm}$ and diastolic more than $80 \mathrm{~mm} \mathrm{Hg}$ ). At the time of diagnosis CPK-MB to CK levels were high in patients having high blood pressure when compared to normotensive group (30\%). The rise in CPK-MB and $\mathrm{CK}$ levels in the present study is in correlation with previous study of J.W. Norris, Hakan Ay.8,9

The rise in CPK-MB and CK levels are in correlation with the CT scan findings, indicating that the origin of CPK-MB is of brain related injury rather than cardiac. However, as a limitation troponin $\mathrm{T}$ levels, which is a sensitive indicator of myocardial injury was not taken in this study.

In the present study uric acid was elevated in 40 cases out of $50(80 \%)$.
The mean value of uric acid in cases was $6.48 \mathrm{mg} / \mathrm{dL}$ with SD of 1.94. The mean value of uric acid in controls was 5.09 with SD 1.07, which is statistically significant.

These findings are in agreement to those of Mehrpour et al who found a higher prevalence of hyperuricemia in patients of acute stroke as compared to the normal population. ${ }^{10}$ Millionis. ${ }^{11}$ et al observed that serum uric acid levels were significantly higher in stroke patients compared with controls (5.6+-1.7 mg/dL vs 4.8+-1.4 mg/dL, $\mathrm{P}<0.001)$. Shrikrishna $\mathrm{R}$ and Suresh DR.12 found that serum uric acid levels were significantly higher in cases as compared to controls (6.56+0.73 vs $4.66+-0.47, \mathrm{P}<0.05$ ). In the Rotterdam study. ${ }^{3}$, higher serum uric acid levels were associated with risk of stroke.

Out of the 50 cases, 30 cases $(60 \%)$ showed increase in SGOT levels and 20 cases showed normal SGOT levels. In 1987 Nand N, Gupta S in the study showed that SGOT levels were elevated in ischaemic stroke patients. ${ }^{14}$ The present study is in correlation with the above study.

Out of 50 cases, 39 cases (78\%) had abnormal lipid profile and 10 had normal lipid profile. The mean and SD value for cholesterol are 215.9 and 26.955 and in controls it is 184.7 and 25.7. The mean and SD value for triglycerides are 146.76 and 16.04. The values of cholesterol and triglycerides indicate that they are important risk factor for ischaemic stroke. Anuradha, Vivek, Debaprity conducted a study in 2014, which indicated the effect of lipid profile in ischaemic stroke patients. ${ }^{15}$ The present study is in correlation with above study and also with study done by JF Albucher, J Ferrieres. ${ }^{16}$

Fasting blood sugar was taken at time of diagnosis. Out of 50 cases, 5 patients had blood sugar level more than 130 $\mathrm{mg} / \mathrm{dL}$ and 45 patients had levels in the normal range. High values in the cases may indicate either a risk factor for ischaemic stroke or may have raised due to stress related injury to brain.

\section{CONCLUSION}

In the present study, CPK-MB levels were elevated in stroke patients indicating the importance of measuring the CPK-MB levels in the diagnosis and prognosis of ischaemic stroke patients. SGOT assays may be important indicator in the prognosis of stroke patients. In the present study, uric acid, cholesterol, and triglycerides were elevated in the cases indicating that they are important risk factor and control of the same may help in preventing stroke. In $10 \%$ cases showed high blood sugar values, which indicate that diabetes is an important risk factor, which should be regulated and treated to prevent ischaemic stroke.

\section{REFERENCES}

1. Intercollegiate Stroke Working Party. National Clinical Guidelines for Stroke. 4th Edition. London, chapter 1.4, 2012:Pg 4.

2. Stephen J, McPhee, Maxine A, et al. Current medical diagnosis and treatment. 52 ${ }^{\text {nd }}$ Edition. USA Chapter 24, 2013:p 979.

3. Colledge NR, Walker B, Ralston SH, et al. Davidson's principles \& practice of medicine. $21^{\text {st }}$ edn. UK Chapter 26, 2010:p 1180.

4. Longo DL, Fauci AS, Kasper DL, et al. Claiborne Johnston Harrison's principal of Internal Medicine. $18^{\text {th }}$ edition. USA Chapter 370, 2012:p 3270. 
5. Dimitroula HV, Hatzitolios AI, Karvounis HI. The role of uric acid in stroke: the issue remains unresolved. Neurologist 2008;14(4):238-42.

6. Kim SY, Guvera JP, Kim KM, et al. Hyperuricemia and risk of stroke: a systematic review and meta analysis. Arthritis Rheum 2009;61(7):885-92.

7. Di Napoli M, Papa F, Baocola V. Prognostic influence of increased C-reactive protein and fibrinogen levels in ischaemic stroke. Stroke 2001;32(1):133-8.

8. Norris JW, Hachinski VC, Myers MG, et al. Serum cardiac enzyme in stroke. Stroke 1979;10(5):548-53.

9. Ay H, Arsava EM, Saribaș O. Creatine kinase-MB elevation after stroke is not cardiac in origin: comparison with troponin T levels. Stroke 2002;33(1):286-9.

10. Mehrpour M, Khuzan M, Najimi N, et al. Serum uric acid level in acute stroke patients. Medical Journal Islamic Republic of Iran 2012;26(2):66-72.

11. Millionis HJ, Kalantzi KJ, Goudevenos JA, et al. Serum uric acid levels and risk for acute ischaemic non-embolic stroke in elderly subjects. J Intern Med 2005;258(5): 435-41.
12. Shrikrishna R, Suresh DR. Biochemical study of antioxidant profile in acute ischaemic stroke. British Journal of Medical Practitioners 2009;2(1):35-7.

13. Bos MJ, Koudstaal PJ, Hofman A, et al. Uric acid is a risk factor for myocardial infarction and stroke: Rotterdam study. Stroke 2006;37(6):1503-7.

14. Nand N, Gupta S, Sharma M, et al. Evaluation of enzymes in serum and cerebrospinal fluid in cases of cerebrovascular accident. Angiology 1987;38(10):750-5.

15. Bharosay A, Bharosay VV, Bandyopadhyay D, et al. Effect of lipid profile upon prognosis in ischaemic and haemorrhagic cerebrovascular stroke. Indian Journal of Clinical Biochemistry 2014;29(3):372-6.

16. Albucher J, Ferrieres J, Ruidavets J, et al. Serum lipids in young patients with ischaemic stroke-a case control study. J Neurol Neurosurgery Psychiatry 2000;69(1): 29-33. 